\title{
Solid-Phase Extraction Method by Magnetic Nanoparticles Functionalized with Murexide for Trace U(VI) from Sea Water Prior to Spectrophotometric Determination
}

\author{
Tülay Oymak \\ Department of Analytical Chemistry, Faculty of Pharmacy, Cumhuriyet University, 58140, Sivas, Turkey \\ *Corresponding author: E-mail: tulayoymak@cumhuriyet.edu.tr \\ Tel: +90346219 Fax: +903462191634
}

Received: 05-06-2018

\begin{abstract}
In this study, magnetic nanoparticles $\left(\mathrm{Fe}_{3} \mathrm{O}_{4} / \mathrm{SiO}_{2} /\right.$ APTES) functionalized with murexide were used for the determination of uranium(VI) in sea water by spectrophotometric method in perchloric acid medium using Arsenazo-III as chromogenic reagent. The effects of some analytical parameters, such as $\mathrm{pH}$, contact time, and eluent volume, on the recovery of uranium(VI) were examined in synthetic sea water. The optimum conditions were achieved with a 15 min adsorption time and 2 min elution time with $1 \mathrm{~mL}$ of $5 \mathrm{~mol} \mathrm{~L}^{-1} \mathrm{HClO}_{4}$ at $\mathrm{pH}$ of 6.5 and $25 \mathrm{mg}$ of the magnetic sorbent. The linear range, detection limit, and precision (as RSD\%) of the method were found to be $0.02-4.0 \mathrm{mg} \mathrm{L}^{-1}, 0.001 \mathrm{mg} \mathrm{L}^{-1}$ and $3.0 \%$, respectively. The proposed method is simple, rapid, and cost-effective for the determination of U(VI) in sea water, with a total analysis time of approximately $30 \mathrm{~min}$. The adsorption isotherm was well fitted to the Langmuir model, with a correlation coefficient of 0.9997 and $Q_{\max }$ value was found to be $77.51 \mathrm{mg} \mathrm{g}^{-1}$. The magnetic sorbent was successfully used for the rapid determination of trace quantities of $\mathrm{U}(\mathrm{VI})$ ions in different sea waters, and satisfactory results were obtained.
\end{abstract}

Keywords: Magnetic nanoparticles; sea water; uranium(VI)

\section{Introduction}

In recent years, environmental pollution with toxic elements, such as uranium, has increased considerably. Uranium and its associated compounds are carcinogenic, dangerously toxic, and radioactive. ${ }^{1-4}$ Furthermore, it can cause respiratory diseases, such as fibrosis and emphysema, and even cause irreversible effects in some tissues, such as the kidneys. Uranium is found in sea water at $3 \mu \mathrm{g} \mathrm{L}^{-1}$ and at approximately $0.0004 \%$ in the Earth's crust. ${ }^{5}$ In many countries, the uranium concentration in drinking water is determined to be $0.03 \mathrm{mg} \mathrm{L}^{-1}$, according to the United States Environmental Protection Agency. ${ }^{6}$ Currently, the determination of uranium in environmental samples is crucial due to applications of uranium in areas, such as in the products of nuclear energy, catalysis, and nuclear weapons. The determination of trace uranium in complex samples and natural waters is a challenging task. Most instruments are not sensitive enough to allow for its determination at very low concentration levels in complex matrix such as sea water. For example the heavy salt matrix reduces sensitivity in direct determinations from sea water (ca. 3.5\% salt). Therefore, a separation and preconcentration step is commonly applied before instrumental analysis. ${ }^{1,6-9}$ Preconcentration/ separation techniques, such as solid phase extraction (SPE), ${ }^{3,10-13}$ liquid-liquid microextraction (LLME), ${ }^{14}$ and cloud point extraction $(\mathrm{CPE})^{15-17}$ are used for the determination of uranium in various samples. SPE has commonly been used as a technique for preconcentration/separation due to its higher enrichment factor and practicality. In SPE, Amberlite-XAD, modified silica gels, mesoporous silica, and nanomaterials are commonly used as adsorbents. ${ }^{18-21}$ Most of these sorbents have disadvantage such as low sorption capacities or efficiencies. Recent studies show that nanomaterials exhibit perfect sorption capacity. But the high dispersibility of nanomatereials in aqueous solutions makes it difficult to separate sorbents from aqueous phase after saturated sorption, which limits their real application in large volumes of waters. ${ }^{22}$ Recently, nanosized iron oxide particles have become an important absorbent in SPE because they show 
magnetic properties, as well as the general properties of nanomaterials. Furthermore, the use of magnetic nanoparticles in SPE has many advantages compared to other adsorbents. For example, magnetic nanoparticles are easily separated from solution with the use of a magnet, low toxicity, and the loss of adsorbent is minimal during the separation. ${ }^{23-27}$ Aside from these advantages, raw $\mathrm{Fe}_{3} \mathrm{O}_{4}$ nanoparticles have several disadvantages, such as oxidation, aggregation tendencies, and low selectivity. However, magnetic nanoparticles can be modified by special ligands to overcome these problems. Magnetic nanoparticles modified with sulfur and nitrogen-containing ligands are preferred because heavy metals react with these ligands strongly and rapidly. ${ }^{28-30}$ Murexide is one of these ligands. ${ }^{18,31}$

In this study, for the quantitative determination of uranium in seawater, a simple and rapid method was developed using an $\mathrm{Fe}_{3} \mathrm{O}_{4}$ nanoparticles modified with murexide. Several experimental parameters, such as $\mathrm{pH}$, contact time, eluent concentration, and sorption capacity, were examined, and the developed method was then applied to real sea water samples.

\section{Experimental}

\section{1. Chemicals and Reagents}

All chemicals used were of analytical reagent grade, and ultrapure water was used throughout the study. Tetraethyl orthosilicate (TEOS), 3-triethoxysilylpropylamine (APTES), iron(II) sulfate heptahydrate, methanol and ethanol were provided by Sigma-Aldrich. Ammonium hydroxide (25\%), iron(III) chloride, hydrochloric acid, $\mathrm{UO}_{2}\left(\mathrm{NO}_{3}\right)_{2} \cdot 6 \mathrm{H}_{2} \mathrm{O}$, dimethyl sulfoxide (DMSO), and murexide were purchased from Merck. Arsenazo-III was obtained from Fluka.

\section{2. Apparatus}

The UV-Vis spectra were recorded using a Shimadzu 3600 spectrophotometer. A Selecta brand $\mathrm{pH}$ metre was used for all $\mathrm{pH}$ measurements. A Biosan multi rotator was employed for the effective mixing of sorbent and solution.

\section{3. Synthesis of Murexide Functionalized Magnetic Nanoparticles}

$\mathrm{Fe}_{3} \mathrm{O}_{4}$ nanoparticles $\left(\mathrm{Fe}_{3} \mathrm{O}_{4}\right.$ NPs) were synthesized with an eco-friendly method, modified from Gautam et al. Briefly, $\mathrm{FeCl}_{3} \cdot 6 \mathrm{H}_{2} \mathrm{O}(6.1 \mathrm{~g})$ was dissolved in deionized water $(100 \mathrm{~mL})$, followed by the addition of a few drops of concentrated $\mathrm{HCl}$ to prevent $\mathrm{Fe}(\mathrm{OH})_{3}$ precipitation. $\mathrm{FeSO}_{4}$ $\cdot 7 \mathrm{H}_{2} \mathrm{O}(4.2 \mathrm{~g})$ was then added to the mixture and heated to $90^{\circ} \mathrm{C}$, followed by the rapid addition of $\mathrm{NH}_{4} \mathrm{OH}(10 \mathrm{~mL}$, $27 \%$ ), with the solution kept at a $\mathrm{pH}$ of 10.0 . The mixture was stirred at $90{ }^{\circ} \mathrm{C}$ for $30 \mathrm{~min}$ and cooled to room temperature. The resulting solid black substance was collected with a strong magnet and washed several times with ethanol and deionized water. The $\mathrm{Fe}_{3} \mathrm{O}_{4} \mathrm{NPs}$ were then dried under vacuum at $60^{\circ} \mathrm{C}$.

To prepare core-shell nanoparticles $\left(\mathrm{Fe}_{3} \mathrm{O}_{4} / \mathrm{SiO}_{2}\right)$, the $\mathrm{Fe}_{3} \mathrm{O}_{4}$ nanoparticles $(0.50 \mathrm{~g})$ were dispersed in a solution of ethanol $(80 \mathrm{~mL})$ and deionized water $(20 \mathrm{~mL})$ by sonicating for $30 \mathrm{~min}$. Then, ammonia solution $(5 \mathrm{~mL}, 27$ wt $\%)$ and TEOS (4 mL) were added sequentially. The mixture was stirred and allowed to react for $6 \mathrm{~h}$ at room temperature. The product, $\mathrm{Fe}_{3} \mathrm{O}_{4} / \mathrm{SiO}_{2}$, was collected by a magnet, washed several times with deionized water, and dried under vacuum at $60{ }^{\circ} \mathrm{C}$ for $8 \mathrm{~h} . \mathrm{Fe}_{3} \mathrm{O}_{4} / \mathrm{SiO}_{2}$ nanoparticles $(1 \mathrm{~g})$ were dispersed in $50 \mathrm{~mL}$ of toluene in a flask. After $1 \mathrm{~h}$, APTES $(4 \mathrm{~mL})$ was added to the mixture, stirred continuously, and refluxed at $125^{\circ} \mathrm{C}$ for $12 \mathrm{~h}$. The magnetic nanoparticles $\left(\mathrm{Fe}_{3} \mathrm{O}_{4} / \mathrm{SiO}_{2} / \mathrm{APTES}\right)$ were separated with a strong magnet and washed several times with deionized water and ethanol, then dried at $70{ }^{\circ} \mathrm{C}$ for $8 \mathrm{~h}$.

In the third step, $\mathrm{Mu}(0.1 \mathrm{~g})$ was dissolved in DMSO $(50 \mathrm{~mL})$, and $\mathrm{Fe}_{3} \mathrm{O}_{4} / \mathrm{SiO}_{2} /$ APTES $(1 \mathrm{~g}$ ) was added to the reaction mixture and refluxed at $200{ }^{\circ} \mathrm{C}$ for $24 \mathrm{~h}$. The resulting product was separated, washed several times with methanol, and dried at room temperature.

\section{4. Procedure}

The method was tested with synthetic sea solutions prior to its application to real sea samples. For this purpose, the synthetic solutions containing the main components present in synthetic sea water (SSW) were prepared at the following concentrations: $\mathrm{Na}^{+}=10569 \mathrm{mg} \mathrm{L}^{-1} ; \mathrm{Mg}^{2+}$ $=1270 \mathrm{mg} \mathrm{L}^{-1} ; \mathrm{K}^{+}=379 \mathrm{mg} \mathrm{L}^{-1} ; \mathrm{Ca}^{2+}=397 \mathrm{mg} \mathrm{L}^{-1} ; \mathrm{BO}_{2}{ }^{-}=$ $18 \mathrm{mg} \mathrm{L}^{-1} ; \mathrm{Cl}^{-}=18990 \mathrm{mg} \mathrm{L}^{-1} ; \mathrm{HCO}_{3}{ }^{-}=139 \mathrm{mg} \mathrm{L}^{-1} ; \mathrm{SO}_{4}{ }^{2-}$ $=2648 \mathrm{mg} \mathrm{L}^{-1} ; \mathrm{Br}^{-}=65.5 \mathrm{mg} \mathrm{L}^{-1} ;$ and $\mathrm{F}^{-}=14 \mathrm{mg} \mathrm{L}^{-1} .13$ $\mathrm{Fe}_{3} \mathrm{O}_{4} / \mathrm{SiO}_{2} /$ APTES (25 mg) was transferred to a $50-\mathrm{mL}$ volumetric flask, and synthetic sea water solutions $(40 \mathrm{~mL})$ were added (U(VI): $\left.0.05 \mathrm{mg} \mathrm{L}^{-1}\right)$. The $\mathrm{pH}$ was adjusted to 6.5 with $0.01 \mathrm{M} \mathrm{CH}_{3} \mathrm{COOH} / \mathrm{NH}_{3}$. The solutions were shaken and allowed to stand for $15 \mathrm{~min}$ at room temperature. The magnetic sorbent was separated from the suspension using a powerful magnet and supernatant was decanted. $1.0 \mathrm{~mL}$ of $5 \mathrm{~mol} \mathrm{~L}^{-1} \mathrm{HClO}_{4}$ was added to the magnetic sorbent with shaking for $2 \mathrm{~min}$ to elute the $\mathrm{U}(\mathrm{VI})$ ion. The magnetic sorbent was separated from the eluent using a magnet.

$\mathrm{U}(\mathrm{VI})$ ion in eluent was determined spectrophotometrically in perchloric acid medium using Arsenazo-III as chromogenic reagent. ${ }^{13}$ To this end, an Arsenazo-III solution $(0.1 \mathrm{~mL}, 0.1 \%)$ was added to eluent solution, and the absorbance of the uranium(VI)-Arsenazo-III complex was measured spectrophotometrically $(653 \mathrm{~nm})$. Finally, the magnetic sorbent was washed with deionized water for reuse. 


\section{Results and Discussion}

\section{1. Characterization of $\mathrm{Fe}_{3} \mathrm{O}_{4} / \mathrm{SiO}_{2} / \mathrm{APTES}$ Functionalized with Murexide}

Scanning electron microscopy (SEM) studies were performed on a Tescan Mira 3XMU with an Oxford EDS analysis system. As shown in Figure 1, the spherical structure of the $\mathrm{Fe}_{3} \mathrm{O}_{4}$ NPs changed after modification. The surface of $\mathrm{Fe}_{3} \mathrm{O}_{4} / \mathrm{SiO}_{2}$ /APTES functionalized with murexide had a rough morphology compared with $\mathrm{Fe}_{3} \mathrm{O}_{4}$. SEM images of $\mathrm{Fe}_{3} \mathrm{O}_{4}$ and $\mathrm{Fe}_{3} \mathrm{O}_{4} / \mathrm{SiO}_{2} /$ APTES functionalized with murexide are shown in Figure 1.

Elemental analysis showed the presence of $\mathrm{C}, \mathrm{N}$ and $\mathrm{Si}$ in the structure of the modified magnetic nanosorbent.
According to the EDS analysis, $\mathrm{Fe}_{3} \mathrm{O}_{4}$ modified with APTES and Mu contains C: $6.71 \%, \mathrm{~N}: 2.90 \%$, Si: $4.06 \%$, O: 49.17\%, and Fe: $37.1 \%$ (Figure 2b).

Infrared absorption measurements of $\mathrm{Fe}_{3} \mathrm{O}_{4}$ and $\mathrm{Fe}_{3} \mathrm{O}_{4} /$ $\mathrm{SiO}_{2} /$ APTES were carried out using a Fourier Transform Infrared (FTIR) spectrophotometer (Bruker Optics - Alpha). The FTIR spectra were obtained in the wavenumber range $500-4000 \mathrm{~cm}^{-1}$ using single bounce ATR with selenium crystal. The absorption peaks at $550 \mathrm{~cm}^{-1}(\mathrm{Fe}-\mathrm{O})$ in the spectra of $\mathrm{Fe}_{3} \mathrm{O}_{4} \mathrm{NPs}$ confirmed the synthesis of $\mathrm{Fe}_{3} \mathrm{O}_{4}$ nanoparticles. ${ }^{32,33}$ On the other hand, the peaks observed at $1045 \mathrm{~cm}^{-1}(\mathrm{Si}-\mathrm{O})$, $1450 \mathrm{~cm}^{-1}(\mathrm{C}=\mathrm{N}), 1530 \mathrm{~cm}^{-1}(\mathrm{C}=\mathrm{C})$ and $1630 \mathrm{~cm}^{-1}(\mathrm{C}=\mathrm{O})$ in the spectra of $\mathrm{Fe}_{3} \mathrm{O}_{4} / \mathrm{SiO}_{2} / \mathrm{APTES} / \mathrm{Mu}$ have shown the successful modification of $\mathrm{Fe}_{3} \mathrm{O}_{4}$ with silan agents and $\mathrm{Mu}^{33}$
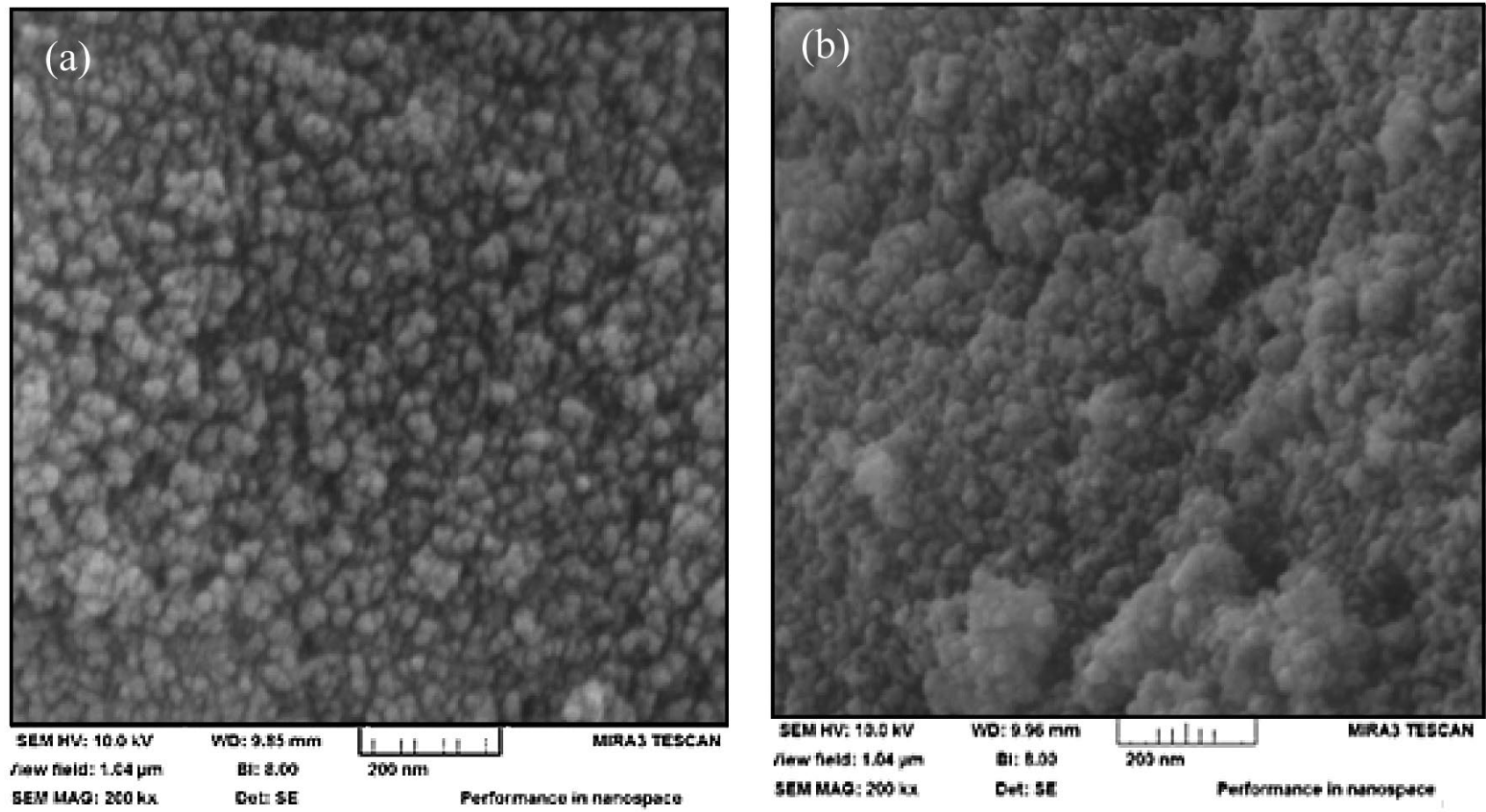

Fig. 1. The Scanning Electron Microscopy images of (a) $\mathrm{Fe}_{3} \mathrm{O}_{4}$ (b) $\mathrm{Fe}_{3} \mathrm{O}_{4} / \mathrm{SiO}_{2} / \mathrm{APTES}$ functionalized with murexide.
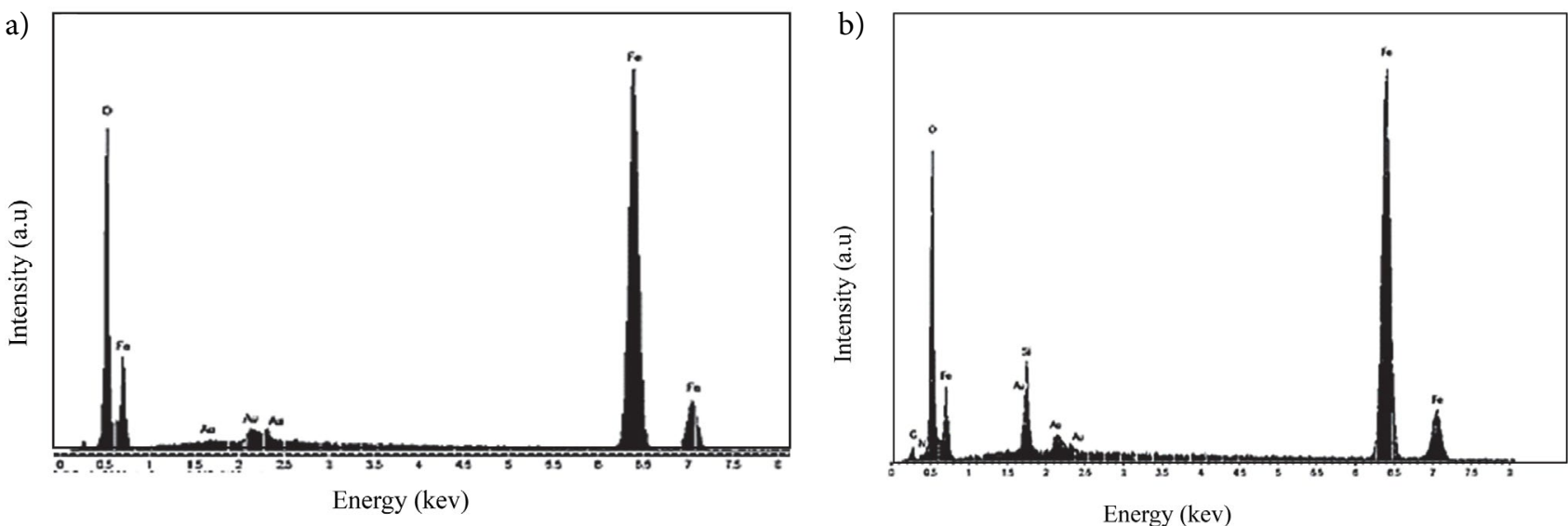

Fig. 2. Energy Dispersive $\mathrm{X}$-Ray Spectroscopy analysis images of (a) $\mathrm{Fe}_{3} \mathrm{O}_{4}$ (b) $\mathrm{Fe}_{3} \mathrm{O}_{4} / \mathrm{SiO}_{2} / \mathrm{APTES}$ functionalized with murexide. 


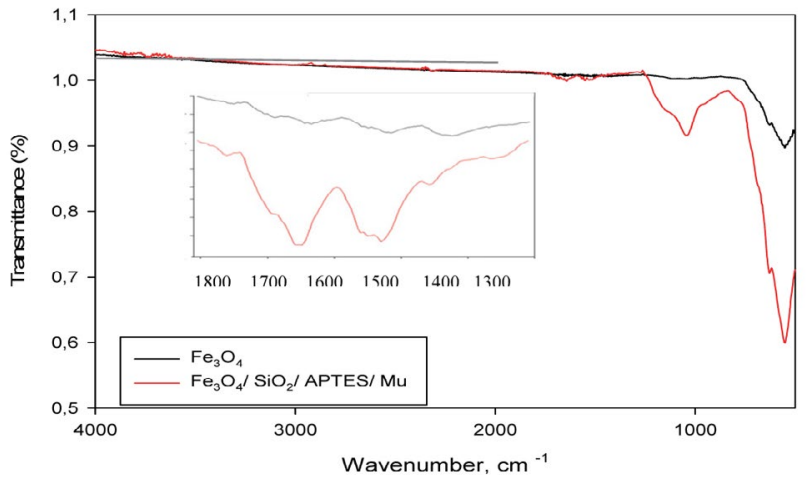

Fig. 3. The FTIR spectra of $\mathrm{Fe}_{3} \mathrm{O}_{4}$ and $\mathrm{Fe}_{3} \mathrm{O}_{4} / \mathrm{SiO}_{2} / \mathrm{APTES}$ functionalized with murexide (the FTIR spectrum of wavenumber 1300$1800 \mathrm{~cm}^{-1}$ is shown ininner figure).

\section{2. Effect of $\mathbf{p H}$}

In the SPE, an important parameter for obtaining the quantitative adsorption and recovery of trace elements is $\mathrm{pH}$. For this purpose, the adsorption of uranium ions on $\mathrm{Mu}$-functionalized $\mathrm{Fe}_{3} \mathrm{O}_{4} / \mathrm{SiO}_{2} /$ APTES sorbent was studied as a function of $\mathrm{pH}$. The $\mathrm{pH}$ of the model solutions ( 40 $\mathrm{mL}, \mathrm{SSW}$ ) containing $50 \mu \mathrm{g} \mathrm{L}{ }^{-1}$ of $\mathrm{U}(\mathrm{VI})$, was adjusted to a $\mathrm{pH}$ range of $4-8$ by the use of relevant buffer solutions; the retained uranium ions were eluted by $\mathrm{HClO}_{4}(1 \mathrm{~mL}, 5 \mathrm{~mol}$ $\left.\mathrm{L}^{-1}\right)$. The graph of retention as a function of $\mathrm{pH}$ is shown in Fig. 4 . The quantitative recovery $(\geq 95 \%)$ for the uranium ions studied was obtained at a $\mathrm{pH}$ of 6-7. Therefore, a $\mathrm{pH}$ of 6.5 was chosen as an optimum $\mathrm{pH}$ for subsequent experiments.

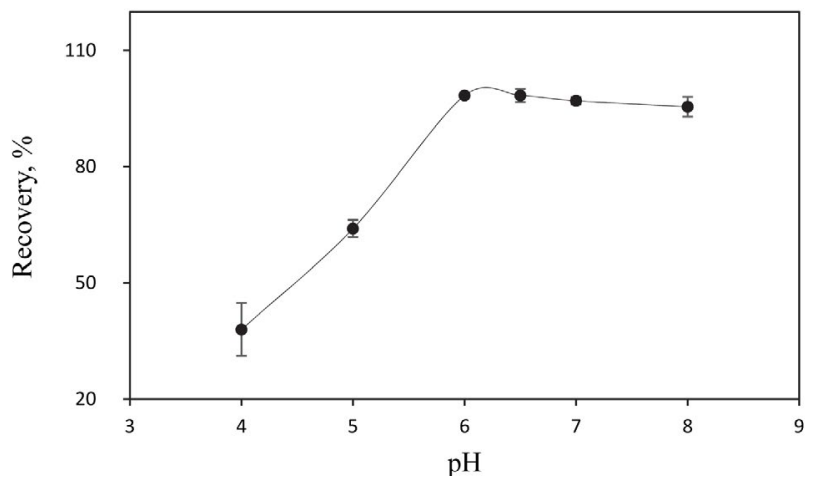

Fig. 4. Effect of $\mathrm{pH}$ on recovery $\% \mathrm{U}(\mathrm{VI})$ with $\mathrm{Fe}_{3} \mathrm{O}_{4} / \mathrm{SiO}_{2} /$ APTES/ $\mathrm{Mu}$.

\section{3. Effect of Eluent Concentration and Volume}

In this study the elution of uranium was studied to find the optimum amount of $\mathrm{HClO}_{4}$ in the range of 2-5 $\mathrm{M}$ and volume of 0.5 to $2 \mathrm{~mL} .1 \mathrm{~mL}$ of $5 \mathrm{M} \mathrm{HClO}_{4}$ was found to be satisfactory for elution of uranium (recovery $\geq 95 \%$ ).
Therefore, $1 \mathrm{~mL}$ of $5 \mathrm{M} \mathrm{HClO}_{4}$ as eluent was chosen for the following experiments.

\section{4. Effect of Matrix Components}

The effects of matrix ions, which are found at high concentrations in real samples, on the recovery of metal ions were studied. Various concentrations of $\mathrm{Fe}^{3+}, \mathrm{Cd}^{2+}$, $\mathrm{Pb}^{2+}, \mathrm{Co}^{2+}, \mathrm{Ni}^{2+}, \mathrm{Cu}^{2+}, \mathrm{Cr}^{3+}, \mathrm{Al}^{3+}$, and $\mathrm{Zn}^{2+}$, as their chloride, nitrate and sulfate salts, were added individually to a model solution of $50 \mathrm{~mL}$ containing $0.05 \mathrm{mg} \mathrm{L}^{-1} \mathrm{U}(\mathrm{VI})$. The described method was applied under optimum conditions. The results are given in Table 1. The most significant interferences were found with $1 \mathrm{mg} \mathrm{L}{ }^{-1}$ of $\mathrm{Cr}^{3+}$ and $\mathrm{Ni}^{2+}$ when determining the presence of uranium. These interferences were prevented by using 0.02 M EDTA. Besides, EDTA can be used as a masking agent for many elements such as Th, Zr, because EDTA forms stable complex with these elements, and unstable complex with U(VI). ${ }^{34}$

Table 1. Tolerance limits for interference ions on the determination of $\mathrm{U}(\mathrm{VI})\left(\mathrm{n}=30,05 \mathrm{mg} \mathrm{L}^{-1} \mathrm{U}, 1 \mathrm{mg} \mathrm{L}^{-1}\right.$ of metal ions)

\begin{tabular}{lcr}
\hline Ion & $\begin{array}{c}\text { Interference ion to } \\
\text { metal ion/ratio }\end{array}$ & $\begin{array}{c}\text { Recovery \%, } \\
\text { U(VI) }\end{array}$ \\
\hline $\mathrm{Zn}^{2+}$ & 20 & $101.4 \pm 4.2$ \\
$\mathrm{Cd}^{2+}$ & 20 & $97.5 \pm 1.8$ \\
$\mathrm{~Pb}^{2+}$ & 20 & $99.2 \pm 0.2$ \\
$\mathrm{Fe}^{3+}$ & 20 & $100.2 \pm 4.3$ \\
$\mathrm{Al}^{3+}$ & 20 & $96.0 \pm 2.3$ \\
$\mathrm{Cr}^{3+}$ & 20 & $81.1 \pm 0.7$ \\
$\mathrm{Cr}^{3+}+0.02$ M EDTA & 20 & $96.2 \pm 0,4$ \\
$\mathrm{Ni}^{2+}$ & 20 & $86.8 \pm 2.4$ \\
$\mathrm{Ni}^{+2}+0.02$ M EDTA & 20 & $97.8 \pm 0,5$ \\
$\mathrm{Cu}^{+2}$ & 20 & $95.4 \pm 1.2$ \\
\hline
\end{tabular}

\section{5. Effect of Adsorption and Elution Time}

The rate of $\mathrm{U}(\mathrm{VI})$ adsorption by $\mathrm{Fe}_{3} \mathrm{O}_{4} / \mathrm{SiO}_{2} / \mathrm{APTES} /$ Mu was studied ( $50 \mathrm{~mL}, 0.05 \mathrm{mg} \mathrm{L}^{-1}$ ) with $25 \mathrm{mg}$ of the sorbent over a series of varying shaking times (5-30 min). The results showed that the extraction percentage of $\mathrm{U}(\mathrm{VI})$ at 15 min was higher than $98 \%$. The rate of elution of $\mathrm{U}(\mathrm{VI})$ by $\mathrm{Fe}_{3} \mathrm{O}_{4} / \mathrm{SiO}_{2} / \mathrm{APTES} / \mathrm{Mu}$ was studied $(50 \mathrm{~mL}$, $0.05 \mathrm{mgL}^{-1}$ ) with $25 \mathrm{mg}$ of the sorbent and an adsorption of $15 \mathrm{~min}$ over a series of varying shaking times ( $1-5 \mathrm{~min}$ ). Therefore, $15 \mathrm{~min}$ and $2 \mathrm{~min}$, respectively, were used in all subsequent experiments for quantitative sorption and elution of $\mathrm{U}(\mathrm{VI})$.

\section{6. Sorption Capacity}

The maximum sorption capacity of $\mathrm{Fe}_{3} \mathrm{O}_{4} / \mathrm{SiO}_{2} /$ APTES/Mu was obtained from the batch methods. A total of $25 \mathrm{mg}$ of $\mathrm{Fe}_{3} \mathrm{O}_{4} / \mathrm{SiO}_{2} /$ APTES/Mu was added to a $40-\mathrm{mL}$ 
solution containing different amounts of U(VI) ions (0.8$8 \mathrm{mg}$ ) at $\mathrm{pH}$ 6.5. After shaking for $1 \mathrm{~h}$, the mixture was separated with the use of a magnet. The supernatant solutions were then measured by UV-Vis spectrophotometry after dilution. Many isotherm models have been proposed to explain the adsorption equilibrium, such as the Langmuir and Freundlich isotherms, which are the most commonly used for the clarification of adsorption of molecules from the liquid phase. The Langmuir equation is given as follows:

$$
\frac{C_{e}}{Q_{e}}=\frac{1}{Q_{\max }} C_{e}+\frac{1}{K Q_{m}}
$$

where $Q_{\max }\left(\mathrm{mg} \mathrm{g}^{-1}\right)$ is the maximum adsorption capacity; $Q_{e}$ is the amount of solute adsorbed per unit weight of adsorbent $\left(\mathrm{mg} \mathrm{g}^{-1}\right)$ at equilibrium; $C_{\mathrm{e}}$ is the equilibrium solute concentration $\left(\mathrm{mg} \mathrm{L}^{-1}\right)$ in solution and $K$ is the Langmuir constant $\left(\mathrm{L} \mathrm{mg}^{-1}\right)$. low: ${ }^{35,36}$

The Freundlich isotherm equation is given be-

$$
Q_{e}=K_{f} C_{e}{ }^{1 / n}
$$

where $Q_{\mathrm{e}}$ is the amount of adsorbed $\mathrm{U}(\mathrm{VI})$ per mass of adsorbent, $K_{\mathrm{f}}$ is the Freundlich constant, $C_{\mathrm{e}}$ is the equilibrium $\mathrm{U}(\mathrm{VI})$ concentration and $1 / n$ is a constant related to the adsorption intensity. ${ }^{37}$

As shown in Table 2, the adsorption mechanism was well-suited to the Langmuir model, with a correlation coefficient of 0.9997 . The $Q_{\max }$ value was found to be 77.51 $\mathrm{mg} \mathrm{g}^{-1}$. The $n$ value was 3.87 , calculated from the Freundlich isotherm, which is higher than 1 . The $n$ value indicated the favourable adsorption of $\mathrm{U}(\mathrm{VI})$ on $\mathrm{Fe}_{3} \mathrm{O}_{4} / \mathrm{SiO}_{2} /$ APTES/Mu. The Langmuir and Freundlich isotherm parameters are shown in Table 2.

\section{7. Analytical Performance and Applications to Real Sea Water Sample}

The limit of detection (LOD) study was performed by applying the described method to ten blank solutions of $40 \mathrm{~mL}$. The limit of detection calculated as the ratio of the three standard deviations of the blank to the slope of plot was $0.001 \mathrm{mg} \mathrm{L}^{-1}$ with a preconcentration factor of 40 . The relative standard deviation was calculated as $3.0 \%$ at 0.05 $\mathrm{mg} \mathrm{L}^{-1}$ of $\mathrm{U}(\mathrm{VI})(\mathrm{n}=7)$ and the linear range in final eluate was $0.02-4.0 \mathrm{mg} \mathrm{L}^{-1}$ of uranium(VI).

The method was successfully applied to sea water. The accuracy of the developed method for sea water was tested by adding the known amounts of U(VI). After applying the separation/ preconcentration procedure, quantitative recovery ( $\geq 95 \%$ ) was found for $\mathrm{U}(\mathrm{VI})$. The results of the analysis of sea water samples are shown in Table 3.

Table 3. The results for determination of $\mathrm{U}(\mathrm{VI})$ in sea water

\begin{tabular}{lccr}
\hline Sample & $\begin{array}{c}\text { Added } \\
\left(\mu \mathrm{g} \mathrm{L}^{-1}\right)\end{array}$ & $\begin{array}{c}\text { Found } \\
\left(\boldsymbol{\mu} \mathbf{g ~ L}^{-1}\right)\end{array}$ & \multicolumn{1}{c}{$\begin{array}{c}\text { Recovery, } \\
\%\end{array}$} \\
\hline Sea water from & 0 & $2.7 \pm 0.1$ & \\
the Aegean Sea & 20 & $22.1 \pm 0.4$ & $97.0 \pm 2.0$ \\
& 40 & $44.2 \pm 0.5$ & $104.0 \pm 1.2$ \\
Sea water from & 0 & $\leq \mathrm{DL}$ & \\
the Mediterranean & 20 & $19.3 \pm 1.0$ & $96.7 \pm 5.3$ \\
& 40 & $40.5 \pm 0.8$ & $101.1 \pm 2.7$ \\
\hline
\end{tabular}

\section{8. Reusability of the Adsorbent}

The reusability of the $\mathrm{Fe}_{3} \mathrm{O}_{4} / \mathrm{SiO}_{2} / \mathrm{APTES} / \mathrm{Mu}$ adsorbent was investigated by adsorption and desorption cycling experiments. The results have shown that the sorbent was stable up to 86 cycles without an obvious decrease in the recoveries. The mean recovery \pm standard deviation from 86 runs was found to be $97.6 \pm 3.6 \%$. This result indicates that the adsorbent possessed a perfect reusability.

\section{Conclusions}

In this paper, $\mathrm{Fe}_{3} \mathrm{O}_{4} / \mathrm{SiO}_{2} / \mathrm{APTES} / \mathrm{Mu}$ was prepared. Then SPE procedure was developed by using these magnetic nanoparticles. The proposed SPE method is simple, fast, practical, and low-cost. The SPE method has a good potential for the extraction of uranium(VI) from sea water. Significant advantages of this method are a short analysis time and satisfactory results in sea water, which has a high salt concentration. In comparison to other SPE methods, the presented method has a low consumption of time, with a total analysis time of approximately $30 \mathrm{~min}$, including the enrichment/separation procedure and the measurement by spectrophotometry. The adsorbent has considerable reusability. The initially synthesized $\mathrm{Fe}_{3} \mathrm{O}_{4} / \mathrm{SiO}_{2} /$ APTES/Mu was used for optimization studies and for a sample application. The adsorbent was reused for $86 \mathrm{cy}-$ cles. The obtained results show that $\mathrm{Fe}_{3} \mathrm{O}_{4} / \mathrm{SiO}_{2} / \mathrm{APTES} /$ $\mathrm{Mu}$ has a good adsorption capacity $\left(77.51 \mathrm{mg} \mathrm{g}^{-1}\right)$. As a result, $\mathrm{Fe}_{3} \mathrm{O}_{4} / \mathrm{SiO}_{2} / \mathrm{APTES} / \mathrm{Mu}$ is indeed an efficient scav-

Table 2. Langmuir and Freundlich isotherm parameters

\begin{tabular}{ccccccc}
\hline & \multicolumn{3}{c}{ Langmuir Parameters } & \multicolumn{3}{c}{ Freundlich Parameters } \\
\hline & $\mathbf{Q}_{\max }\left(\mathbf{m g ~ g}^{-\mathbf{1}}\right)$ & $\mathbf{K}\left(\mathbf{L} \mathbf{~ m g}^{-\mathbf{1}}\right)$ & $\mathbf{R}^{\mathbf{2}}$ & $\mathbf{K}_{\mathbf{f}}\left(\mathbf{L} \mathbf{~ m g}^{-\mathbf{1}}\right)$ & $\mathbf{n}$ & $\mathbf{R}^{\mathbf{2}}$ \\
\hline $\mathrm{U}(\mathrm{VI})$ & 77.51 & 0.896 & 0.9997 & 26.22 & 3.87 & 0.9455 \\
\hline
\end{tabular}


enger for $\mathrm{U}(\mathrm{VI})$ in sea water in terms of its fast sorption time, large sorption capacity, selectivity, easy separation and good reusability of the material.

\section{Acknowledgement}

This work is supported by the Scientific Research Project Fund of Cumhuriyet University under the project number ECZ-040.

\section{References}

1. M. Rezaee, F. Khalilian, Journal of Radioanalytical and Nuclear Chemistry 2015, 304, 1193-1200.

DOI:10.1007/s10967-015-3951-6

2. S. Saeed, H. Davarani, H. Reza, A. Reza, M. Hossein, S. Nojavan, Analytica Chimica Acta 2013, 783, 74-79. DOI:10.1016/j.aca.2013.04.045

3. M. Tuzen, E. Bagda, B. Hazer, Journal of Radioanalytical and Nuclear Chemistry 2016, 310, 1255-1263.

DOI:10.1007/s10967-016-4949-4

4. D. Mwalongo, N. K. Mohammed, Radiation Physics and Chemistry 2013, 91, 15-18.

DOI:10.1016/j.radphyschem.2013.06.002

5. S. R. Tetgure, B. C. Choudhary, D. J. Garole, A. U. Borse, A. D. Sawant, S. Prasad, Microchemical Journal 2017, 130, 442-451.

DOI:10.1016/j.microc.2016.10.019

6. T. S. Anirudhan, L. Divya, P. S. Suchithra, Journal of Environmental Management 2009, 90, 549-560.

DOI:10.1016/j.jenvman.2007.12.010

7. J. Kim, C. Tsouris, R. T. Mayes, Y. Oyola, J. Kim, C. Tsouris, R. T. Mayes, et al., Separation Science and Technology 2013, 48, 367-368.

DOI:10.1080/01496395.2012.712599

8. E. Schneider, D. Sachde, Science \& Global Security 2017, 21, 9882

9. S. Shahida, A. Ali, M. H. Khan, Journal of the Iranian Chemical Society 2014, 11, 1-8.

10. A. Nilchi, T. S. Dehaghan, S. R. Garmarodi, Journal of Radioanalytical and Nuclear Chemistry 2013, 295, 2111-2115. DOI:10.1007/s10967-012-2252-6

11. S. Durani, M. Krishnakumar, K. Satyanarayana, Journal of Radioanalytical and Nuclear Chemistry 2012, 294, 215-220. DOI:10.1007/s10967-011-1610-0

12. A. Khayambashi, X. Wang, Y. Wei, Hydrometallurgy 2016, 164, 90-96.

DOI:10.1016/j.hydromet.2016.05.013

13. O. Hazer, S.Kartal, Talanta 2010, 82, 1974-1979.

DOI:10.1016/j.talanta.2010.08.023

14. R. Rodriguez, J. Avivar, L. Ferrer, L. O. Leal, V. Cerdi, Talanta 2015, 134, 674-680.

DOI:10.1016/j.talanta.2014.12.007

15. C. Labrecque, S. Potvin, L. Whitty-Léveillé, D. Larivière, Talanta 2013, 107, 284-291.

DOI:10.1016/j.talanta.2013.01.049
16. S. Gao, T. Sun, Q. Chen, X. Shen, Journal of Hazardous Materials 2013, 263, 562-568.

DOI:10.1016/j.jhazmat.2013.10.014

17. J. B. Ghasemi, B. Hashemi, M. Shamsipur, Journal of the Iranian Chemical Society 2012, 9, 257-262.

18. A. Tadjarodi, A. Abbaszadeh, M. Taghizadeh, N. Shekari, A. A. Asgharinezhad, Materials Science and Engineering $C$ 2015, 49, 416-421.

DOI:10.1016/j.msec.2015.01.013

19. M. Wierucka, M. Biziuk, TrAC - Trends in Analytical Chemistry, 2014, 59, 50-58.

DOI:10.1016/j.trac.2014.04.007

20. S. Sadeghi, E. Sheikhzadeh, Journal of Hazardous Materials, 2009, 163, 861-868

DOI:10.1016/j.jhazmat.2008.07.053

21. D. Li, S. Egodawatte, D.I. Kaplan, S.C. Larsen, S. M. Serkiz, J. C. Seamand, Journal of Hazardous Materials, 2016, 317, 494-502

DOI:10.1016/j.jhazmat.2016.05.093

22. Y. Zhao, J. Li, L. Zhao, S. Zhang, Y. Huang, X. Wua, X.Wang, Chemical Engineering Journal, 2014, 235, 275-283 DOI:10.1016/j.cej.2013.09.034

23. X. Liu, J. Xing, Y. Guan, G. Shan, H. Liu, Colloids and Surfaces A: Physicochemical and Engineering Aspects 2004, 238, 127-131.

DOI:10.1016/j.colsurfa.2004.03.004

24. R. K. Gautam, P. K. Gautam, S. Banerjee, S. Soni, S. K. Singh, M. C. Chattopadhyaya, Journal of Molecular Liquids 2015, 204,60-69.

DOI:10.1016/j.molliq.2015.01.038

25. C. Hu, J. Deng, Y. Zhao, L. Xia, K. Huang, S. Ju, N. Xiao, Food Chemistry 2014, 158, 366-373.

DOI:10.1016/j.foodchem.2014.02.143

26. M. Hidarian, S. Hashemian, Oriental Journal of Chemistry 2014, 30, 1753-1762.

27. X. Qin, A. A. A. Bakheet, X. Zhu, Journal of the Iranian Chemical Society 2017, 14, 2017-2022.

28. C. Atila Dincer, N. Yildiz, N. Aydogan, A. Calimli, Applied Surface Science 2014, 318, 297-304.

DOI:10.1016/j.apsusc.2014.06.069

29. Y. Huang, A. A. Keller, Water Research 2015, 80, 159168. DOI:10.1016/j.watres.2015.05.011

30. S. Sánchez-Rodríguez, J. Trujillo-Reyes, E. Gutiérrez-Segura, M. Solache-Ríos, A. Colín-Cruz, Separation Science and Technology 2015, 50, 1602-1610.

DOI:10.1080/01496395.2014.986579

31. Y. Izadmanesh, J. B. Ghasemi, Talanta 2014, 128, 511517. DOI:10.1016/j.talanta.2014.06.008

32. R. S. Juang, Yao. C. Yei, C. S. Lia, K. S. Lind, H. C. Lu, S. F.Wang, A. C. Sun, Journal of the Taiwan Institute of Chemical Engineers 2018, 90, 51-60.

DOI:10.1016/j.jtice.2017.12.005

33. A. A. Asgharinazed, M. Rezvani, H. Ebrahimzadeh, N. Shekari, N. Ahmandinasab, M. Loni, Analytical Methods, 2015, 7, 10350-10358.

DOI:10.1039/C5AY02362A 
34. A. H. Orabi, Journal of Radiation Research And Applied Sciences, 2013, 6, 1-10.

DOI:10.1016/j.jrras.2013.09.001

35. Q. Zhou, F. Chen, W. Wu, R. Bu, W. Li, F. Yang, Chemical Engineering Journal 2016, 285, 198-206.

DOI:10.1016/j.cej.2015.10.004
36. T. Robinson, B. Chandran, P. Nigam, Water Research 2002, 36, 2824-2830.

DOI:10.1016/S0043-1354(01)00521-8

37. C. Kannan, K. Muthuraja, M. R. Devi, Journal of Hazardous Materials 2013, 244-245, 10-20.

DOI:10.1016/j.jhazmat.2012.11.016

\section{Povzetek}

$\mathrm{V}$ tej raziskavi smo uporabili magnetne nanodelce $\left(\mathrm{Fe}_{3} \mathrm{O}_{4} / \mathrm{SiO}_{2} /\right.$ APTES), funkcionalizirane $\mathrm{z}$ mureksidom, za določanje urana(VI) v morski vodi s spektrofotometrično metodo v perklorno-kislinskem mediju z Arsenazo-III kot kromogenim reagentom. Vpliv nekaterih analiznih parametrov, kot so $\mathrm{pH}$, kontaktni čas in volumen eluenta, na izkoristek ekstrakcije urana(VI) smo raziskovali v sintetski morski vodi. Optimalne pogoje smo dosegli z adsorpcijskim časom 15 min in elucijskim časom 2 min pri eluciji z $1 \mathrm{~mL} 5 \mathrm{~mol} \mathrm{~L}^{-1} \mathrm{HClO}_{4}$ pri pH 6,5 in s $25 \mathrm{mg}$ magnetnega sorbenta. Linearno območje, meja zaznave in natančnost (kot RSD\%) metode so bili: $0,02-4,0 \mathrm{mg} \mathrm{L}^{-1}, 0,001 \mathrm{mg} \mathrm{L}^{-1}$ in $3,0 \%$. Predlagana metoda je preprosta, hitra in cenovno ugodna za določanje U(VI) v morski vodi s skupnim časom analize približno 30 min. Adsorpcijska izoterma se je dobro prilegala Langmuirjevemu modelu s korelacijskim koeficientom 0,9997 in vrednostjo $Q_{\max } 77,51 \mathrm{mg} \mathrm{g}^{-1}$. Magnetni sorbent smo uspešno uporabili za hitro določitev U(VI) ionov v sledovih v različnih vzorcih morske vode ter dobili zadovoljive rezultate. 